\title{
Impact of Paternalistic Leadership on Organizational Readiness for Change: Mediating Role of Employee Engagement and Moderating Role of Islamic Work Ethics
}

\author{
Muhammad Qaiser Shafi ${ }^{1 *}$, Ali Raza ${ }^{2}$, Ali Haider Bajwa ${ }^{3}$, Nafla Gul ${ }^{4}$ \\ ${ }^{1,4}$ Faculty of Management Sciences, Riphah International University, Islamabad, Pakistan \\ ${ }^{2}$ Quaid-i-Azam School of Management Sciences, Quaid-i-Azam University, Islamabad, Pakistan \\ ${ }^{3}$ Faculty of Management Sciences, International Islamic University, Islamabad, Pakistan
}

\section{Keywords}

Paternalistic Leadership

Organizational Readiness

Employee Engagement

Islamic Work Ethics

Received: 21 July 2020

Accepted: 07 November 2020

\begin{abstract}
.
Purpose: This study aims to investigate the impact of paternalistic leadership on organizational readiness for change: mediation of employee engagement and moderation of Islamic work ethics (IWE). Methodology: The sample size for this research is 203. The data were collected from faculty of private and public sector educational institutes that were in process of change. SPSS has been utilized for data analysis. Findings: Using Leader-Member Exchange (LMX) as a theoretical lens, the results indicate paternalistic leadership significantly positively impacts organizational readiness for change; employee engagement acts as a mediating agent between paternalistic leadership and organizational readiness for change; IWE moderates between the relationship of paternalistic leadership and employee engagement.

Significance: The mediation of employee engagement and moderation of IWE between paternalistic leadership and organizational readiness for change is still under research so this makes our research a unique contribution.

Limitations: This research shall add to the Islamic ethical principles of employees alongside output which will advantage the organization as well as employees.

Implications: This research has managerial implications for change agents, organizational development (OD) consultants; policymakers of educational institutions, and professionals regarding change strategies, benefits, and the Islamic business environment.
\end{abstract}

KAUJIE Classification: $\mathrm{H} 48$, T6

JEL Classification: M12, M5

\footnotetext{
*Corresponding author: Muhammad Qaiser Shafi

${ }^{\dagger}$ Email: qaiser.shafi@ riphah.edu.pk; ORCID: https://orcid.org/0000-0003-0697-313X
} 


\section{INTRODUCTION}

Knowledge to manage organizational change and successful execution of change programs can be simplified by analysis of individual willingness to change. Armenakis and Fredenberger (1997) defined readiness as "a mindset that exists among employees during the implementation of organizational changes. It comprises of belief, attitude and intention of change target members regarding the need for and capability of implementing organizational change" (p. 144). The perception of readiness is exciting for workforce' feedbacks to change, it plays a significant part in organizational change (Bartunek \& Rousseu, 2006; Oreg \& Vocalla, 2011). Moreover, readiness is a prime factor, intricate in preliminary support of employees for change imaginations (Armenakis \& Fredenberger, 1993; Holt et al., 2007). Organizational readiness for change is a multidimensional concept influenced by opinions in the mindset of employees that they have skills to execute a future change because it is good for the organization, moreover, they have management support and the proposed change is beneficial for employees (Armenakis et al., 2007). Leadership is a central issue for discussion (House et al., 2004). Our zone of attention is paternalistic leadership, paternalistic is a prosperous part of management literature, but there is still debate between researchers that how to describe paternalistic leadership and its success. Despite, different authors have different definitions of paternalistic leadership, but the recent definition of paternalistic leadership is "a style that combines strong discipline and authority with fatherly benevolence" (Farh \& Cheng, 2000).

The human relation effort indicates that if leaders are team-focused, instead of instrumentalization, workers would be more mollified and more creative (Bassu \& Green, 1997). So, when a manager becomes paternalistic and has good behavior with his employees then it's easy to bring change in the organization and employees are ready for the change. Studies on paternalistic evolution from Asia disparate Weber's controlling idea and claimed that paternalistic leaders be responsible for cooperation and look after their dependents (Redding et al., 1994). Mostly work on paternalistic leadership has been done in the Asia region but with different variables, here we examine that how readiness of change in an organization occurs when a leader is paternalistic. As per the literature, most research studies have been done on organization change for readiness by taking different leadership styles, but here in this research paper we took paternalistic leadership style and examined its impact on organization readiness for change, moreover added Islamic work ethics and employee engagement.

Though, the majority of research work in this domain, as well as in the larger subject field of business ethics, has been carried out on the experiences in the American and few European countries (Lim, 2003; Rizk, 2008). In Muslim countries, this concept is still under-researched. Islam e.g. has its code of conduct that is derivative from the Holy Qur'ān and Sunnah. In a manner alike Weberian Protestantism, Islam gives the conceptual basis for a range of individual qualities that endorse financial growth (Ali, 1992). Up to now, only a few scholars have worked on IWE (Ali, 1992; Ali \& Al-Kazemi, 2007; Rahman et al., 2006). Since Pakistan is an Islamic republic, where most of the organizational work is based on Islamic principles. Therefore based on this contextual reality, it is essential to explore the effect of IWE. The studies by multiple authors have highlighted that Islamic work ethics 
impact most of the organizational decisions concerning their precursors (Ahmad et al., 2019; Din et al., 2019; Nasution \& Rafiki, 2019). As per the literature, there exists a gap to address IWE as a moderator between leadership style and change management.

Employee engagement is another construct that needs to be focused on during the process of organizational change. It is defined as "a positive, fulfilling, work-related state of mind that is characterized by vigordin, dedication, and absorption" (Schaufeli et al., 2002). Modern organizations need to rely on those employees who put in extra effort, are committed, and give their best. Previous studies show that employee engagement is key to a competitive edge from an organizational point of view (Bakker \& Schaufeli, 2008; Macey \& Schneider, 2008). Employee engagement has a critical role in organizational readiness to change; this importance has been highlighted by many researchers that this relationship needs to be explored (Makikangas et al., 2019; Mitra et al., 2019; Roczniewska \& Higgins, 2019). The creativity embedded in the paternalistic leadership leads to organizational readiness to change and this aspect is currently missing in the literature (Du \& Luo, 2020; Karakitapoglu-Aygun et al., 2020; Nazir et al., 2020; Soomro et al., 2020). Using LMX as a theoretical lens, the objective of our research is to address the research gap to inspect the association between paternalistic leadership and organizational readiness to change with the mediation of employee engagement and moderation of IWE (Khan \& Gul, 2020). This all literature evidence highlights the gap which still exists in the literature and this study will contribute to fulfilling this gap.

The target sector chosen for our research is public and private universities. The rationale behind choosing public and private universities is that now educational institutions are moving towards enterprise resource planning (ERP) from traditional/ conventional learning management systems. Secondly, to suggest implications for change agents; OD consultants, policymakers of educational institutions, and professionals regarding change strategies, benefits, and Islamic business environment. This research paper contributes knowledge about the crucial role of paternalistic leadership during organizational change as change is a must for survival and growth in the 21 st century.

\section{LITERATURE REVIEW}

\section{Paternalistic Leadership}

Paternalistic leadership is a form of fatherly managerial style, which is used to manage and protect employees who are expected to be faithful and respectful. A paternalistic leader is appropriate for an organization where the structure is the formal and hierarchical and creative thinking of subordinates is not required. Gelfand et al. (2007) defined paternalism as "a hierarchical relationship in which a leader guides professional and personal lives of subordinates in a manner resembling a parent and in exchange expects loyalty and admiration". Paternalistic leadership is "a style that combines strong discipline and authority with fatherly benevolence" (Farh \& Cheng, 2000). Researches point out that paternalistic leadership is not a cohesive concept; it has 03 dimensions: authoritarianism, benevolence, and morality (Aycan, 2006; Farh \& Cheng, 2000). Authoritarianism speaks of a leader's behavior that has strong control \& authority over its assistants and wants undisputed respect from them. 
Chinese managers set up a centralized structure to frequently ratify these standards and assume a father-like role with a straight \& commanding leadership style (Peng et al., 2001). Benevolence indicates that a leader shows apprehension for his assistant's personal and family life. Mortality defined a leader's behavior that shows greater ethical charisma and honesty by acting generously and leading from the front. Allah directs a leader to show the power of his examples instead of the examples of his power (3:51). Leader-Member Exchange (LMX) theory gives details about paternalistic leadership and recent research from Turkey found LMX to be an important link of paternalistic leadership. According to Pellegrini and Scandura (2006), paternalism indicates voluntary obedience, then, an assistant who practices high levels of belief, responsibility, and obedience in their dealings with a leader (i.e. LMX) may admit the leader's power as a father. Moreover, paternalism requires a significant investment by a leader, \& for that reason, leaders may be keener to involve in paternalistic activities with followers with whom they have good-quality LMX relationships. Overall, paternalistic leadership is a father-like role and provides protection, care, and safety to the workers' professional and individual lives demanding faithfulness and obedience (Pelegrini \& Scandura, 2008).

\section{Organization Readiness for Change}

Readiness is debatably one of the major issues intricate in workers' preliminary support for change steps and activities (Armenakis et al., 1999). However the idea of readiness might be initially presented by Jacobson (1957) the basis for readiness as a distinctive concept has been inserted within numerous conceptual frameworks of the procedure by which change dissolve. For this purpose, over the past few years, vast numbers of research studies were conducted in this area of change management to examine the predictive elements of employee's readiness towards organizational change and its diverse levels of effect (Armenakis et al., 1993; Chawla \& Kelloway, 2004; Cinite et al., 2009; Cunningham et al., 2002; Erturk, 2008; Madsen et al., 2005; Peach et al., 2005; Rafferty \& Simon, 2006). Various theories, theoretical frameworks, and empirical research studies have been applied to examine numerous features of organizational change. Therefore, literature implies that employee's readiness is more effective for the successful execution of organizational change programs (Eby et al., 2000; Madsen et al., 2005; Rafferty \& Simon, 2006). A researcher has shown that the support of employees for the execution of organizational change will direct an organization to develop dynamic change (Cinite et al., 2009; Jones et al., 2005). However, literature also explains that employees in an organization are further multifaceted henceforth, their awareness views, and attitude turns into serious and competitive in successfully implementing change programs (Armenakis et al., 1993; Weber \& Weber, 2001). So, change experts, are working to discover a possible diverse grouping of positive employee readiness aspects to motivate employees' readiness for successfully executing organizational change (Cunningham et al., 2002; Madsen et al., 2005).

\section{Paternalistic Leadership and Organizational Readiness for Change}

Schneider et al. (1996) highlighted the significance of establishing an atmosphere for organizational change. If people don't agree on the change that exists in the organization then 
the organization can't go for change (Schneider et al., 1996). Lewin's (1951) several papers discussed a three-step process to implement change. First organization unfreeze their current system and then in the second phase in which an organization moves where it wants to go and third Re-freeze stage in which organization currently at most wanted state and changes become established. Research shows that readiness for change is like Lewin's un-freezing concept (Armenakis et al., 2009). A message for change should revolve among members of the organization and employees should have self-assurance that they have the aptitude to bring changes (Armenakis \& Harris, 2002). It is explained that Readiness-creating message will have more effect if the person is more honest, and genuine that convey a message (Armenakis \& Harris, 2009). So concerning leadership, if the leader acts as a change representative, as in many circumstances, then change readiness takes place in the organization as workers trust and respect their leader. As in the introduction, it shows that that first time we see the impact of paternalistic leadership on readiness for change so, here we see the impact of transformational and transactional leadership on readiness for change because transformational and transactional leaders are the same as Paternalistic Leaders. As per Bass (1985), transactional leadership is a process in which leaders are responsible for reward and punish for employees' performance as in one dimension of paternalistic leadership authoritarianism also speaks about how leaders have strong control or authority over their assistants. Bass (1985) also shows that transformational leadership has positive qualities like charisma, care about the individual, aptitude, and willingness to provide intellectual motivation as other dimensions of paternalistic leadership benevolence: leader shows care for his assistants and mortality defined a leader's that have charismatic personality and honesty through acting generously and leading by example. As explained by definition that transformational leaders pay more attention to change. A real transformational leader transforms the thinking, views, and attitude of supporters (Podsakoff et al., 1990). At the corporate level, a transformational leader is who brings initiation, implement new ways in the organizations (Northouse, 2004). Therefore, an efficient transformational leader is capable to bring change to the organization. Previous studies support this concept. For example, Graetz (2000) used a qualitative case study and his result shows that a leader must have the vision, authorized, and strengthen his or her followers. The distinctiveness that Graetz (2000) explained is the dimensions of the transformational leader as well as paternalistic leader behavior. It is showed that the transformational leader's behavior was linked with lower-level worker's cynicism as regards organizational change. Transactional leadership will also be significantly positively related to organizational readiness for change but less. So transactional leaders don't provide a vision for the organization so employees are uncertain and feel hesitant to involve in change activates. Based on the above arguments, we hypothesize that

H1: Paternalistic leadership significantly positively affects Organization readiness for change.

\section{Paternalistic Leadership and Organization Readiness for Change: Mediating Role of Employee Engagement}

The term employee engagement is established mainly by researchers of business studies, management, organizational behavior (OB) discipline, and psychology (Welch, 2011). Many 
researchers described Employee engagement as a "satisfying, positive job-related skill, state of mind and it also existed as a good health and positive work affect at the workplace" (Schaufeli \& Bakker, 2004; Sonnentag, 2003). Employee engagement has 03 dimensions: vigor, dedication, and absorption (Schaufeli et al., 2002). It shows a significant impact on output and employee retention by executing employee engagement (Bhatnagar, 2007). Engaged employees tend to be more concerned about their organization's success and go the extra mile to achieve success (Glaspie \& Nesbitt 2004, James et al., 2011). Leadership is deliberated in relation to help employee's engagement in the literature (Suharti \& Suliyanto, 2012). The behavior of a leader with its subordinates affects employee's engagement in the organization (Saks, 2006). Moreover, leaders' support and care for employees is set up of a positive relationship on employee engagement. If the leader shows more concern and welcomes the opinion of its subordinates, the work engagement is higher than expected to be (Suharti \& Suliyanto, 2012). Furthermore, there is a positive influence of benevolent and moral leadership on the outcomes of employees (Wang \& Cheng, 2010). It is found in a study that there exists a significant positive association between these dimensions and subordinate performance (Wang et al., 2011). However, authoritarian leadership style contains control over their subordinates, so a lot of research has found that there is a negative relationship between authoritarian leadership style and employee job attitudes (Chan et al., 2013). However, numerous studies have revealed that leader authorizing behavior towards employees has a positive impact on their work engagement (Mendes \& Stander, 2011). It is found that employee engagement has a role in organizational readiness for change. Employee engagement shows a vital role in employee acceptance of the change (Iverson, 1996; Yousef, 2000). It is also found that highly committed workers are more ready to accept organizational change if it is beneficial for them (Lau \& Woodman 1995). Studies show that employees who are highly engaged in their work are more willing to put effort to bring change to the organization, so it is showed that they develop a positive attitude towards organizational change (Iverson, 1996).

H2: Employee engagement significantly and positively affects organization readiness for change.

H3: Employee engagement mediates the relationship between Paternalistic leadership and Organization readiness for change.

\section{Paternalistic Leadership and Employee Engagement: Moderation of Islamic Work Ethics}

The word "ethics" is derived from the Greek word "ethos" which means "character" (Ahmet \& Akdogan, 2012). The terminology "IWE" is drawn from Weber"s theory of protestant work ethics (Qayyum et al., 2018). Islamic work ethics is the behavior that's either forbidden or encouraged for employees at the workplace in overcoming hurdles delaying the success of an organization (Yousef, 2000). Islamic work ethics forbid idleness, laziness at the workplace, and wasting time in unproductive work, it is believed that the person who has done these kinds of action at the workplace is usually unproductive and fails in life because of their attitude. It is a new aspect of business ethics to improve the workplace environment in an 
organization. Employees who implement Islamic work ethics in their workplace not only perform better but also have good behavior with their colleagues (Khan et al., 2015).

Employees face many problems related to ethics at their workplace like corruption, lying, bullying, stealing, and monetary cons. Islam shows the standards of success for Muslims that do their daily activities and business activates according to Qur'ān and Hadith and it is openly detected that only those get success who invite others towards good (Yousef, 2000). The Holy Qur'ān puts too much emphasis on ethics as "You are the best nation has been raised for mankind; you enjoin right conduct, forbid evil and believe in Allah" (3:110). "And let there be from you a group inviting to all to that is good (Khair), enjoining what is right (maruf), and forbidding what is wrong (munkar)" (3:104). The eventual message of the Holy Qur'ān and Sunnah teaches and orders the best of ethics in the personal as well as professional life of an individual (Athar et al., 2016). Islamic values have its impact on leadership styles. It is showed that the spiritual abilities of managers affect transformational and charismatic leadership and paternalistic leadership (Bekis, 2006). In Middle East countries, leadership styles tend to be highly strict as Islam supports loyalty, respect, and obedience for superiority to work-related values (Yeganeh \& Su, 2008). Thus in western countries, management styles lead towards high performance. In the Arab world, significances are classically focused on family safety, family coordination, and paternalism while in the United States of America effort is on independence, liberty, and self-assurance.

H4: Islamic work ethics moderates the relationship between Paternalistic leadership and employee engagement in such a way that this relationship gets stronger when IWE is high.

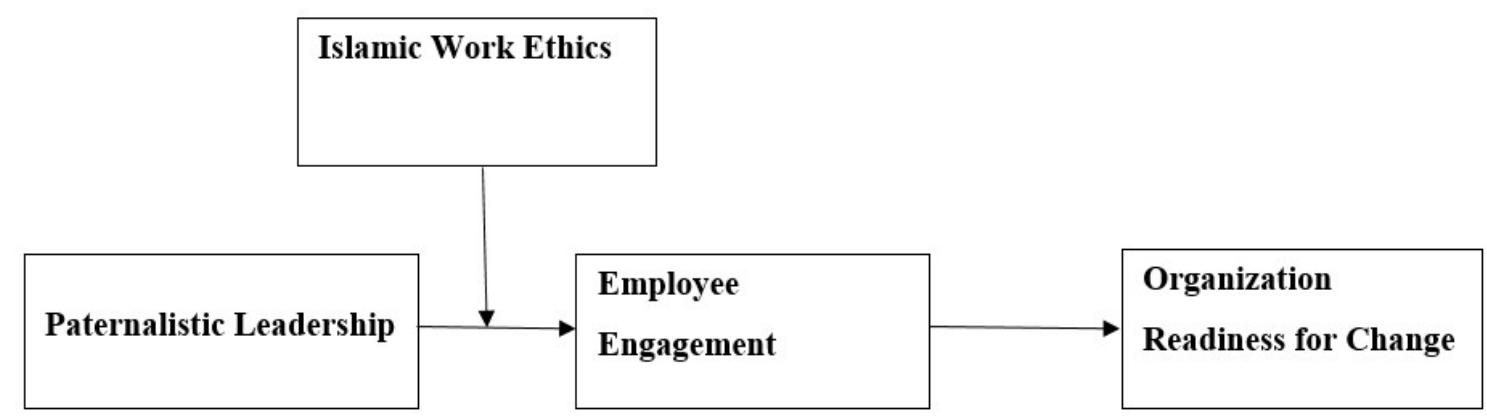

FIGURE 1. Research Model

\section{METHODOLOGY}

Participants of the Study

In Pakistan, now most organizations bring technology and new methods to survive in this competitive environment, so for that purpose employee readiness is more effective for the 
successful execution of organizational change program. Leadership is the most important element for an employee's readiness, when employees have faith in their leaders they can easily go for a change. This can be experimental in most of the organizations in Pakistan. Therefore, the data is collected from two educational institutions that recently went through the technological change process. The convenience sampling technique has been used to collect data from the teaching faculty of private and public sector educational institutions of Pakistan. Total 400 questionnaires were distributed from which 253 were completed and returned, 50 were partially filled and thus not utilizable making the response rate $50.75 \%$. As part of research ethics, all members were guaranteed privacy and confidentiality to guarantee the rationality of their reactions. As far as demographics are concerned, most of the participants were married (70\%) males (83.3\%) with an average age from 26 to 40 years $(67.5 \%)$. The majority of them were Assistant professors and administrative jobs (46.8\%) and as far as experience is concerned, $57.5 \%$ of respondents were having less than 10 years of experience.

\section{Scales/ Measures Used}

All variables of study in hand have been measured using a 5 point Likert scale where 1 symbolized Strongly Disagree and 5 symbolized Strongly Agree.

\section{Paternalistic Leadership}

PL was measured using a 17 item scale developed by Cheng et al. (2000). Sample item contained "My supervisor handles what is difficult to do or manage in everyday life for me". The Cronbach alpha for this variable was 0.753 .

\section{Islamic Work Ethics}

IWE was measured using a 17 item scale developed by Ali (1992). Sample items included "Dedication to work is a virtue." The alpha for this scale was 0.941 .

\section{Employee Engagement}

Employee Engagement has been measured using a 09 item scale developed by Schaufeli et al. (2006). Sample items included "Today, I was proud of work that I do". The Cronbach's alpha reliability for this variable is 0.877 .

\section{Readiness for Change}

Readiness for change was measured by using 6 item scale developed by Holt et al. (2007). Sample items included "I usually try to convince people in my company to accept change". The Cronbach's alpha for this scale was 0.748 .

TABLE 1

One-way ANOVA

\begin{tabular}{lll}
\hline \hline & \multicolumn{2}{l}{ Readiness for Change } \\
\hline & F. Statistics & P-Value \\
\hline Gender & 9.37 & .01 \\
Age & 6.29 & .00 \\
Marital Status & 5.85 & .02 \\
Position & 38.15 & .00 \\
Job Tenure & 9.18 & .00 \\
\hline \hline
\end{tabular}




\section{Control Variables}

A one-way ANOVA test was done to resist the disparity in readiness for change based on demographic variables used in the study. Findings showed that one-way ANOVA (see Table 1) point out important variances in the readiness for change i.e. dependent variable through gender $(F=9.37, p<.01)$, age $(F=6.29, p<.00)$, marital status $(\mathrm{F}=5.85, p<.02)$, position $(F=38.15, p<.00)$ and job tenure $(F=9.18, p<.00)$. After that, factors recognized as significant were moved as control variables in step one of regression analysis.

\section{RESULTS}

Mean, Standard deviation, and Correlation results are presented in Table 2.

TABLE 2

Mean, S.D and correlation

\begin{tabular}{lllllll}
\hline \hline & Mean & S.D & 1 & 2 & 3 & 4 \\
\hline PL & 3.44 & .403 & & & & \\
ROC & 3.67 & .535 & $.259^{* *}$ & & & \\
IWE & 3.66 & .778 & $.231^{* *}$ & $.589^{* *}$ & & \\
EE & 3.58 & .532 & $.356^{* *}$ & $.451^{* *}$ & $.577^{* *}$ & 1 \\
\hline ** Correlation is significant at the 0.01 level (2-tailed).
\end{tabular}

$N=203, \mathrm{PL}=$ Paternalistic Leadership, ROC $=$ Readiness for Change

IWE= Islamic Work Ethics, EE= Employee Engagement

The table point toward that Paternalistic leadership has a significant positive correlation with organization readiness for change $(0.259, p \leq 0.05)$ which gives preliminary support for hypothesis 1 . On the other hand, paternalistic leadership has significant positive relationship with IWE $(0.231, p \leq 0.05), \&$ EE $(0.356, p \leq 0.05)$. IWE displayed a positive association with $\operatorname{ROC}(0.581, p \leq 0.05)$. EE showed positive correlation with $\operatorname{ROC}(0.451, p \leq 0.05)$.

\section{Regression Analysis Moderation}

Regression analysis was performed to check the variation in the dependent variable because of demographics, independent, mediator, and moderator. The findings got from the regression analysis are presented in Table 3. 
TABLE 3

Regression analysis-moderation

\begin{tabular}{llll}
\hline \hline & \multicolumn{3}{c}{ Readiness for Change } \\
\hline Step 1 & $\beta$ & $R^{2}$ & $\Delta R^{2}$ \\
\hline Control Variable & \multicolumn{3}{c}{0.127} \\
Step 2 & \multicolumn{4}{c}{} \\
PL & $.126^{* *}$ & & \\
IWE & $.464^{* *}$ & 0.470 & 0.343 \\
Step 3 & & & \\
PLxIWE & $.983^{* *}$ & 0.605 & 0.135 \\
\hline \hline N=203, Pl = Paternalistic Leadership, IWE $=$ Islamic \\
work ethic and EE = Employee Engagement $=p<.00^{* *}$
\end{tabular}

Hypothesis 4 was tested by using moderated regression analysis; where the control variable was entered in Step One. In step two, Independent and moderator variables were entered. At the end of step three, the interaction term (product of IV and moderator variable) was entered, which if comes significant, verifies moderation.

The result of moderated regression analysis is presented Table 3 (Step 3) indicate that IWE moderates the relationship between PL and employee engagement $\left(\beta=0.983, p<0.05 ; \Delta R^{2}\right.$ 0.135), and as a result hypothesis H4 is supported.

\section{Mediation Analysis}

As for the $\mathrm{H} 3$ is concerned, it was supposed that employee engagement mediates the relationship between PL and ORC. The mediation method as proposed by Preacher and Hayes (2008) is used for this analysis.

TABLE 4

Mediated regression analysis

\begin{tabular}{lllll}
\hline \hline & $\mathrm{B}$ & $\mathrm{SE}$ & $\mathrm{T}$ & $\mathrm{p}$ \\
\hline $\mathrm{PL} \rightarrow$ ORC & .3450 & .0906 & 3.8070 & .0002 \\
$\mathrm{PL} \rightarrow \mathrm{EE}$ & .4704 & .0871 & 5.4003 & .0000 \\
$\mathrm{EE} \rightarrow$ ORC & .1504 & .0892 & 1.6856 & .0000 \\
$\mathrm{PL} \rightarrow \mathrm{EE} \rightarrow$ ORC & .4138 & .0675 & 6.1306 & .0000
\end{tabular}

Bootstrap results for an indirect effect

Indirect effect LL 95\% CI UL 95\% CI

$\begin{array}{lll}.1947 & .1129 & .2822\end{array}$

Table 4 gives a summary of the mediation analysis performed. Initially, it was found that $\mathrm{PL}$ is positively related to $\mathrm{ORC}(\beta=.3450, p<0.05) ; \mathrm{H} 1$ is supported. It is found that PL is positively related to $\mathrm{EE}$ ( $\beta=0.4704, p<0.05)$; $\mathrm{EE}$ is positively related to ORC ( $\beta=$ $.1504, \mathrm{p}<0.05$ ) indicates $\mathrm{H} 2$ is supported. And finally, it is found that the PL to ORC in the 
presence of mediator $(\beta=.4138, p<0.05)$. Both LL and UL have the same positive sign and don't contain zero in between, which indicates that partial mediation exists. Hence H3 is supported.

\section{DISCUSSION}

The analysis supported all hypotheses of this study. Paternalistic leadership was found to have a positive effect on organizational readiness for change of the employee. When an organization introduces new technologies and wants a change in the organization, it is only possible when employees are ready for the change. So, concerning leadership, people respect and trust their leader, and if the leader represents a change agent that change is possible. That means when companies changing processes, want loyalty and attachment of worker and want to bring the change they should follow a paternalistic leader style to bring positive employee reactions rather than bring change without any planning which may have a negative impact on employees. These findings are in line with previous studies (Podsakoff et al., 1990, Northouse, 2004), researchers have long suggested that PL May develop ROC. Employee engagement has a significant positive relation with paternalistic leadership and organizational readiness for change. Actions of a leader with his assistant's effect employee's engagement in the organization. Moreover, employee engagement shows a very important role in employee acceptance of the change. It is meant that when companies want to change then they also have a look at employee engagement in their organization because it is very easy for managers to bring change after those findings. Past studies also support that EE positively affects PL and ROC (Wang \& Cheng 2010).

Employee engagement shows a vital role in employee acceptance of the change (Yousef, 2000; Iverson 1996). Studies show that employees who are highly engaged with the organization are more willing to put effort to bring change to the organization, so it is showed that they develop a positive attitude towards organizational change (Iverson, 1996).

Islamic Work Ethics indicates that it has a significant positive relationship with paternalistic leadership and employee engagement. These results are reliable with our view that the Islamic code of conduct inspires followers to obtain and share their knowledge with their colleagues. The Holy Qur'ān shows the importance of being polite, modest, and helpful in both personal and professional life. Islam shows the values of achievement for Muslims that do in their daily actions and occupation activates according to Qur'ān and Hadith, only those get success who invite others towards good (Yousef, 2000). Islamic values have its impact on leadership styles. It is showed that the spiritual abilities of managers affect transformational and charismatic leadership (paternalistic leadership) (Bekis, 2006). In Middle East countries, leadership styles tend to be highly strict as Islam supports loyalty, respect, and obedience for superiority to work-related values (Yeganeh \& Su, 2008). Therefore, the results of the study in hand support the preceding intellectual arguments on the role of IWE in affecting PL and EE. 


\section{Theoretical Implications}

Using LMX as a theoretical lens, the present study tested the mediating role of employee engagement and the moderating role of Islamic Work Ethics between the relationship of paternalistic leadership and organizational readiness for change.

\section{Managerial and Practical Implications}

Top management like Chancellors, VC's, Deans, and Head of departments (HOD's) are suggested to offer their workforce a helpful business setting, particular attention must be given to engaging employees in seminars, workshops, and training where the major focus may be emphasizing the welfare of continues development and loyalty with the organization and leader. In the same way, managers should follow and focus on emerging the Islamic culture where Islamic principles, code of conduct, and ethical values are provided. Islamic code e.g. ākhirah, itqān, muhāasabah, ijtimā' $\bar{\imath} y a h$, and mushawārah, etc is an entire set of values for every phase of human life. It shall add to the Islamic ethical principles of employees alongside output which will advantage the organization as well as employees.

\section{Limitations and Direction for Future Research}

The data has been gathered from the faculty of only 02 private and public sector educational institutions of Pakistan, which recently went through the change process. Further studies are recommended to be conducted on the same subject matter in other emerging Asian countries to enhance the generalizability of this study. The study in hand included a sample size of 203 respondents which was selected by using the convenience sampling technique. To reassure the generalizability of the present study, researchers are suggested to use a larger sample size in the future. Future studies must also take into account multi-source data collection methods to avoid common method bias. This research is an outcome of Paternalistic leadership's impact on organizational readiness for change. It is suggested that researchers may study other leadership styles e.g. Laissez-Faire leadership, spiritual leadership, servant leadership that is being mostly followed in Asian countries.

\section{Conclusion}

To conclude, organization readiness for change is not only vital but also is a requirement of the 21st century for organizational survival and growth, and secondly, paternalistic leadership plays a crucial role during organizational change. Our research paper contributes to the knowledge about the leadership role in change management. Our work may also instigate the organizations to think about the fatherly leadership style, employee engagement, and Islamic ethical values, which lead organizations to successfully manage the organizational change and may increase their success and productivity.

\section{REFERENCES}

Ahmad, Z., Rahim, N. A., Chulan, M., Ab Wahab, S. A., \& Noor, A. N. M. (2019). Islamic work ethics and organizational citizenship behavior among Muslim employees in educational institutions. Proceedings of the Second International Conference on the 
Future of ASEAN, 1, 455-464). doi: https://doi.org/10.1007/978-981-10-8730-1_46 Ahmet, N., \& Akdogan, C. (2012). Trust (Al-Amanah): A comparative study of its application in Islamic and western science. Paper presented at the Asian Conference Ethics, Religion Philosophy, Japan.

Ali, J. A., \& Al-Kazemi, A. (2007).Managerial problems in Kuwait. The Journal of Management Development, 21(5), 366-375. doi: https://doi.org/10.1108/02621710210426853

Ali, J.A. (1992). Islamic work ethic in Arabia. Journal of Psychology, 126 (5), 507-517. doi: https://doi.org/10.1080/00223980.1992.10543384

Armenakis, A. A., \& Fredenberger, W. (1997). Organizational change readiness practices of business turnaround change agents. Knowledge and Process Management, 4(4), 143-152. doi: https://doi.org/10.1002/(SICI)1099-1441(199709)4:3<143::AID-KPM93>3.0.CO;27

Armenakis, A. A., \& Harris, S. G. (2002). Crafting a change message to create transformational readiness. Journal of Organizational Change Management, 15(2), 169-170. doi: https://doi.org/10.1108/09534810210423080

Armenakis, A. A., Berneth, J. B., Pitts, J. P., \& Walker, H. J. (2007). Organizational change recipients' beliefs scale: Development of an assessment instrument. Journal of Applied Behavioral Science, 43(2), 495-505.

doi: https://doi.org/10.1177/0021886307303654

Armenakis, A. A., Harris, S. G., \& Feild, H. S. (1999). Making change permanent: A model for institutionalizing change interventions. In W. A. Pasmore \& R. W. Woodman (Eds.), Research in organizational change and development (Vol. 12). JAI. doi: https://doi.org/10.1016/S0897-3016(99)12005-6

Armenakis, A. A., Harris, S. G., \& Mossholder, K.W. (1993). Creating readiness for organizational change. Human Relations, 46(6), 681-702.

doi: https://doi.org/10.1177/001872679304600601

Armenakis, A. A., \& Harris, S. G. (2009). Reflections: our journey in organizational change research and practice. Journal of Change Management, 9(2), 127-142.

doi: https://doi.org/10.1080/14697010902879079

Athar, M. R., Shahzad, K., Ahmad, J., \& Ijaz, M. S. (2016). Impact of Islamic work ethics on organizational commitment: Mediating role of job satisfaction. Journal of Islamic Business and Management, 6(1), 397-416.

Aycan, Z. (2006). Paternalism: Towards conceptual refinement and operationalization. In K. S. Yang, K. K. Hwang, \& U. Kim (Eds.), Indigenous and cultural psychology: Understanding people in context. Springer.

Bakker, A. B., \& Schaufeli W. B. (2008). Positive organizational behavior: Engaged employees in flourishing organizations. Journal of Organizational Behavior, 29, 147154. doi: https://doi.org/10.1002/job.515

Bartunek, J. M., Rousseau, D. M., Rudolph, J. W., \& Palma, J.A. (2006). On the receiving end: sense-making, emotion, and assessments of an organizational change initiated by others. Journal of Applied Behavioral Science, 42(2), 182-206.

doi: https://doi.org/10.1177/0021886305285455 
Bass, B. M. (1985). Model of transformational leadership. In T. F. Mech, \& G. B. McCabe, (Eds.), Leadership and academic librarians. Greenwood.

Bekis, T. (2006). A practical study about spiritual intelligence in leadership (Master's thesis). Selcuk University, Konya, Turkey.

Bhatnagar, J., (2007). Talent management strategy of employee engagement in Indian ITES employees: Key to retention. Employee Relations, 29(6), 640-663.

doi: https://doi.org/10.1108/01425450710826122

Chan, K. L., Gligoris, T., Upcher, W., Kato, Y., Shirahige, K., Nasmyth, K., \& Beckouet, F. (2013). Pds5 promotes and protects cohesin acetylation. Proceedings of the National Academy of Sciences of the United States of America, 110(32), 13020-13025. doi: https://doi.org/10.1073/pnas.1306900110

Chawla, A., \& Kelloway, E.K. (2004). Predicting openness and commitment to change. Leadership $\mathcal{F}$ Organization Development Journal, 25(5/6), 485-486.

doi: https://doi.org/10.1108/01437730410556734

Cheng, B. S., Chou, L. F., \& Farh, J. L. (2000). A triad model of paternalistic leadership: Its constructs and measurement. Indigenous Psychological Research in Chinese Societies, 14, 3-64. doi: https://doi.org/10.1037/t35288-000

Cinite, I., Duxbury, L. E., \& Higgins, C. (2009). Measurement of perceived organizational readiness for change in the public sector. British Journal of Management, 20, 265-27. doi: https://doi.org/10.1111/j.1467-8551.2008.00582.x

Cunningham, C. E., Woodward, C. A., Shannon, H. S., MacIntosh, J., Lendrum, B., Rosenbloom, D., \& Brown, J. (2002). Readiness for organizational change: A longitudinal study of workplace, psychological and behavioral correlates. Journal of Occupational and Organizational Psychology, 75(4), 377-392.

doi: https://doi.org/10.1348/096317902321119637

Du, J., Li, N. N., \& Luo, Y. J. (2020). Authoritarian leadership in organizational change and employees' active reactions: Have-to and willing-to perspectives. Frontiers in psychology, 10, 3076. doi: https://doi.org/10.3389/fpsyg.2019.03076

Eby, L. T., Adams, D. M., Russell, J. E., \& Gaby, S. H. (2000). Perceptions of organizational readiness for change: Factors related to employees' reactions to the implementation of team-based selling. Human relations, 53(3), 419-442.

doi: https://doi.org/10.1177/0018726700533006

Erturk, A. (2008).A trust-based approach to promote employee's openness to organizational change in Turkey. International Journal of Manpower, 29, 462-483. doi: https://doi.org/10.1108/01437720810888580

Farh, J. L., \& Cheng, B. S. (2000). A cultural analysis of paternalistic leadership in Chinese organizations. In J. T. Li, A. S. Tsui, \& E. Weldon (Eds.), Management and organizations in the Chinese context. Macmillan. doi: https://doi.org/10.1057/9780230511590_5

Farh, J. L., Cheng, B. S., Chou, L. F., \& Chu, X. P. (2006). Authority and benevolence: Employees' responses to paternalistic leadership in China. In A. S. Tsui, Y. Bian, \& L. Cheng (Eds.), China's domestic private firms: Multidisciplinary perspectives on management and performance. Sharpe. 
Gelfand, M. J., Erez, M., \& Aycan, Z. (2007). Cross-cultural organizational behavior. Annual Review of Psychology, 58, 479-51.

doi: https://doi.org/10.1146/annurev.psych.58.110405.085559

Glaspie, P., \& Nesbitt, M. (2004). Employee engagement: Readership institute report. Northwestern University, Evanston, IL.

Graetz, F. (2000). Strategic change leadership. Management Decision, 38(8), 550-564. doi: https://doi.org/10.1108/00251740010378282

Holt, D. T., Armenakis, A. A., Feild, H. S., \& Harris, S. G. (2007). Readiness for organizational change: The systematic development of a scale. Journal of Applied Behavioral Science, 43(2), 232-255. doi: https://doi.org/10.1177/0021886306295295

House, R. J., Hanges, P. J., Javidan, M., Dorfman, P. W., \& Gupta, V. (2004). Culture, leadership, and organizations: The GLOBE study of 62 societies. Sage.

Iverson, R. D. (1996). Employee acceptance of organizational change: The role of organizational commitment. International Journal of Human Resource Management, 7(1), 122-149. doi: https://doi.org/10.1080/09585199600000121

Jacobson, E. H. (1957). The effect of changing industrial methods and automation on personnel. Paper presented at the Symposium on Preventive and Social Psychology, Washington, DC.

James, J. B., McKechnie, S., \& Swanberg, J. (2011). Predicting employee engagement in an age-diverse retail workforce. Journal of Organizational Behavior, 32(2), 173-196. doi: https://doi.org/10.1002/job.681

Jones, R. A., Jimmieson, N. L., \& Griffiths, A. (2005). The impact of organizational culture and reshaping capabilities on change implementation success: The mediating role of readiness for change. Journal of Management Studies, 42(2), 361-386.

doi: https://doi.org/10.1111/j.1467-6486.2005.00500.x

Karakitapoglu-Aygun, Z., Gumusluoglu, L., \& Scandura, T. A. (2020). How do different faces of paternalistic leaders facilitate or impair task and innovative performance? Opening the black box. Journal of Leadership E Organizational Studies, 27(2), 138-152. doi: https://doi.org/10.1177/1548051819833380

Khan, A. A., \& Gul, A. (2020). Interactive effects of paternalistic leadership and Islamic work ethics on employees' psychological safety: Evidence from Pakistan. Journal of Islamic Business and Management, 10(1), 202-219.

doi: https://doi.org/10.26501/jibm/2020.1001-013

Khan, K., Abbas, M., Gul, A., \& Raja, U. (2015). Organizational justice and job outcomes: Moderating role of Islamic work ethic. Journal of Business Ethics, 126(2), 235-246. doi: https://doi.org/10.1007/s10551-013-1937-2

Lau, C. M., \& Woodman, R. W. (1995). Understanding organizational change: A schematic perspective. Academy of Management Journal, 38(2), 537-554.

doi: https://doi.org/10.2307/256692

Lewin, K. (1951). Field theory in social science. Harper and Row.

Lim, C., \& Lay, C.S. (2003). Confucianism and the protestant work ethic. Asia Europe Journal, 3(1), 321-322. doi: https://doi.org/10.1007/s10308-003-0038-8 
Macey, W.H., \& Schneider, B. (2008). The meaning of employee engagement. Industrial and Organizational Psychology, 1(1), 3-30.

doi: https://doi.org/10.1111/j.1754-9434.2007.0002.x

Madsen, S. R., Miller, D., \& John, C. R. (2005). Readiness for organizational change: Do organizational commitment and social relationships in the workplace make a difference. Human Resource Development Quarterly, 16(2), 213-214. doi: https://doi.org/10.1002/hrdq.1134

Makikangas, A., Mauno, S., Selenko, E., \& Kinnunen, U. (2019). Toward an understanding of a healthy organizational change process: A three-wave longitudinal study among university employees. International Journal of Stress Management, 26(2), 204-212. doi: https://doi.org/10.1037/str0000059

Mendes, F., \& Stander, M. W. (2011). Positive organisation: The role of leader behaviour in work engagement and retention. SA Journal of Industrial Psychology, 37(1), 1-13. doi: https://doi.org/10.4102/sajip.v37i1.900

Mitra, A., Gaur, S. S., \& Giacosa, E. (2019). Combining organizational change management and organizational ambidexterity using data transformation. Management Decision, 57(8), 2069-2091. doi: https://doi.org/10.1108/MD-07-2018-0841

Nasution, F. N., \& Rafiki, A. (2019). Islamic work ethics, organizational commitment, and job satisfaction of Islamic banks in Indonesia. RAUSP Management Journal, 55(2), 195-205. doi: https://doi.org/10.1108/RAUSP-01-2019-0011

Nazir, S., Shafi, A., Asadullah, M. A., Qun, W., \& Khadim, S. (2020). Linking paternalistic leadership to follower's innovative work behavior: The influence of leader-member exchange and employee voice. European Journal of Innovation Management. doi: https://doi.org/10.1108/EJIM-01-2020-0005

Northouse, P. G. (2004). Leadership: Theory and practice (3rd ed.). Sage Publications Ltd.

Oreg, S., Vakola, M., \& Armenakis, A. (2011). Change recipients' reactions to organizational change: A sixty-year review of quantitative studies. Journal of Applied Behavioral Science, 47(4), 461-524. doi: https://doi.org/10.1177/0021886310396550

Peach, M., Jimmieson, N. L., \& White, K. M. (2005). Beliefs underlying employee readiness to support a building relocation: A theory of planned behavior perspective. Organization Development Journal, 23(3), 9-10.

Pellegrini, E. K., \& Scandura, T. A. (2006). Leader-Member Exchange (LMX), paternalism and delegation in the Turkish business culture: An empirical investigation. Journal of International Business Studies, 37, 264-279. doi: https://doi.org/10.1057/palgrave.jibs.8400185

Pellegrini, E. K., \& Scandura, T. A. (2008). Paternalistic leadership: A review and agenda for future research. Journal of Management, 34, 566-593. doi: https://doi.org/10.1177/0149206308316063

Peng, M. W., Lu, Y., Shenkar, O., \& Wang, D. Y. L. (2001). Treasures in the China house: A review of management and organizational research on Greater China. Journal of Business Research, 52, 95-110. doi: https://doi.org/10.1016/S0148-2963(99)00063-6 
Podsakoff, P. M., Mackenzie, S. B., Moorman, R. H., \& Fetter, R. (1990). Transformational leader behaviors and their effects on followers' trust in leader, satisfaction, and organizational citizenship behaviors. The Leadership Quarterly, 1, 107-142. doi: https://doi.org/10.1016/1048-9843(90)90009-7

Preacher, K. J., \& Hayes, A. F. (2008). Asymptotic and resampling strategies for assessing and comparing indirect effects in multiple mediator models. Behavior Research Methods, 40(3), 879-891. doi: https://doi.org/10.3758/BRM.40.3.879

Qayyum, A., Kousar, S., Jamil, R. A., \& Sarmad, M. (2018). Relationship between workfamily and interpersonal conflicts: Mediating role of psychological distress and the moderating effect of Islamic work ethics. Journal of Islamic Business and Management, 8(2), 501-519. doi: https://doi.org/10.26501/jibm/2018.0802-010

Rafferty, A. E., \& Simons, R. H. (2006). An examination of the antecedents of readiness for fine-tuning and corporate transformation changes. Journal of Business and Psychology, 20(3), 325-327. doi: https://doi.org/10.1007/s10869-005-9013-2

Rahman, N. M., Muhammad, N., \& Othman, A. S. (2006). The relationship between Islamic work ethics and organizational commitment: A case analysis. Malaysian Management Review, 41(1), 79-89.

Redding, S. G., Norman, A., \& Schlanders, A. (1994). The nature of the individual attachment to theory: A review of East Asian variations. In H. C. Triandis, M. D. Dunnett, \& L. M. Hough (Eds.), Handbook of industrial and organizational psychology. Consulting Psychology Press.

Rizk, R.R. (2008). Back to basics: An Islamic perspective on business and work ethics. Social Responsibility Journal, 1(2), 246-254. doi: https://doi.org/10.1108/17471110810856992

Roczniewska, M., \& Higgins, E. T. (2019). Messaging organizational change: How regulatory fit relates to openness to change through fairness perceptions. Journal of Experimental Social Psychology, 85, 103882. doi: https://doi.org/10.1016/j.jesp.2019.103882

Saks, A. M. (2006). Antecedents and consequences of employee engagement. Journal of Managerial Psychology, 21(7), 600-619. doi: https://doi.org/10.1108/02683940610690169

Schaufeli, W. B., \& Bakker, A. B. (2004). Job demands, job resources, and their relationship with burnout and engagement: A multi-sample study. Journal of Organizational Behavior: The International Journal of Industrial, Occupational and Organizational Psychology and Behavior, 25(3), 293-315. doi: https://doi.org/10.1002/job.248

Schaufeli, W. B., Bakker, A. B., \& Salanova, M. (2006). The measurement of work engagement with a short questionnaire: A cross-national study. Educational and Psychological Measurement, 66(4), 701-716. doi: https://doi.org/10.1177/0013164405282471

Schaufeli, W. B., Salanova, M., Gonzalez-Roma, V., \& Bakker, A. B. (2002). The measurement of engagement and burnout: A confirmative analytic approach. Journal of Happiness Studies, 3, 71-92.doi: https://doi.org/10.1023/A:1015630930326

Schneider, B., Brief, A. P., \& Guzzo, R. A. (1996). Creating a climate and culture for sustainable organizational change. Organizational Dynamics, 24, 6-19. doi: https://doi.org/10.1016/S0090-2616(96)90010-8 
Sonnentag, S. (2003). Recovery, work engagement, and proactive behavior: a new look at the interface between nonwork and work. Journal of Applied Psychology, 88(3), 518-520. doi: https://doi.org/10.1037/0021-9010.88.3.518

Soomro, B. A., Memon, M., \& Shah, N. (2020). Paternalistic leadership style, employee voice, and creativity among entrepreneurs. Management Decision, 59(2), 285-305. doi: https://doi.org/10.1108/MD-11-2018-1207

Suharti, L., \& Suliyanto, D. (2012). The effects of organizational culture and leadership style toward employee engagement and their impacts toward employee loyalty. World Review of Business Research, 2(5), 128-139.

Wang, A. C., \& Cheng, B. S. (2010). When does benevolent leadership lead to creativity? The moderating role of creative role identity and job autonomy. Journal of Organizational Behavior, 31(1), 106-121. doi: https://doi.org/10.1002/job.634

Wang, Z. J., Long, L. R., \& Liu, L. D. (2011). Operation mechanism and effects of supervisor-subordinate Guanxi in Chinese organizations. Acta Psychologica Sinica, 43(07), 798-809.

Weber, P. S., \& Weber, J. E. (2001).Changes in employee perceptions during organizational change. Leadership $\mathcal{E}$ Organization Development Journal, 22(5), 291-295. doi: https://doi.org/10.1108/01437730110403222

Welch, M. (2011). The evolution of the employee engagement concept: Communication implications. Corporate Communications: An International Journal, 16(4), 328-346. doi: https://doi.org/10.1108/13563281111186968

Yeganeh, H., \& Su, Z. (2008). An examination of human resource management practices in Iranian public sector. Personnel Review, 37(2), 203-221. doi: https://doi.org/10.1108/00483480810850542

Yousef, D. A. (2000). Organizational commitment and job satisfaction as predictors of attitudes toward organizational change in a non-western setting. Personnel Review, 29(5-6), 6-25. 